\title{
NEW RECORDS OF GALL CRABS (DECAPODA, CRYPTOCHIRIDAE) FROM ORCHID ISLAND, TAIWAN, NORTHWESTERN PACIFIC
}

\section{BY}

\section{TSUI-PING WEI ${ }^{1}$ ), JIANG-SHIOU HWANG ${ }^{1,4}$ ), MIN-LI TSAI ${ }^{2}$ ) and LEE-SHING FANG ${ }^{3}$ )}

1) Institute of Marine Biology, National Taiwan Ocean University, 2 Pei-Ning Road, Keelung 202, Taiwan, R.O.C.

2 ) Department of Life Science, National Pingtung University of Science and Technology, Pingtung 912, Taiwan, R.O.C.

3 ) National Museum of Marine Biology and Aquarium, Pingtung 944, Taiwan, R.O.C.

\begin{abstract}
Orchid Island (Lan-Yu) $\left(22^{\circ} 1^{\prime} \mathrm{N} 121^{\circ} 5^{\prime} \mathrm{E}\right)$, Taitung county, a remote island off Taiwan, harbours well developed hard coral communities. These may provide various favourable habitats for their obligate symbionts, gall crabs. Until now, not even a single species of these crabs had been recorded from Orchid Island. For this study, we collected hard corals by SCUBA diving at the coral reefs surrounding Orchid Island. We identified nine species of gall crabs belonging to nine genera. They include Cryptochirus coralliodytes inhabiting Goniastrea australensis; Lithoscaptus paradoxus on G. australensis; Hiroia krempfi on Hydnophora exesa; Neotroglocarcinus hongkongensis on Turbinaria mesenterina and T. peltata; Pseudocryptochirus viridis on T. mesenterina; Dacryomaia edmonsoni on Psammocora contigua; Opecarcinus crescentus on Coscinaraea columna and Pavona venosa; Utinomiella dimorpha on Pocillopora verrucosa; and Hapalocarcinus marsupialis on $P$. verrucosa. Including the new records from Orchid Island in this study, the established brachyuran crab fauna of Taiwan now stands at 611 species.
\end{abstract}

\section{RÉSUMÉ}

Orchid Island (Lan-Yu) $\left(22^{\circ} 1^{\prime} \mathrm{N} 121^{\circ} 5^{\prime} \mathrm{E}\right)$, Taitung county, une île éloignée au large de Taiwan, abrite des communautés de coraux bien développées. Celles-ci fournissent des habitats variés, favorables à leurs symbiontes obligés que sont les crabes qui forment des galles. Jusqu'à présent, pas une seule espèce de ces crabes n'avait été recensée à Orchid Island. Pour cette étude, nous avons récolté des coraux durs en utilisant la plongée sous-marine (SCUBA) dans les récifs entourant l'île. Nous $\mathrm{y}$ avons identifié neuf espèces de crabes formant des galles, appartenant à neuf genres différents. Ce sont Cryptochirus coralliodytes, vivant sur Goniastrea australensis ; Lithoscaptus paradoxus sur G. australensis ; Hiroia krempfi sur Hydnophora exesa ; Neotroglocarcinus hongkongensis sur Turbinaria mesenterina et T. peltata; Pseudocryptochirus viridis sur T. mesenterina; Dacryomaia edmonsoni sur Psammocora contigua; Opecarcinus crescentus sur Coscinaraea columna et Pavona

${ }^{4}$ ) Author for correspondence; Fax: +886-2-2462-9464; e-mail: Jshwang@mail.ntou.edu.tw 
venosa ; Utinomiella dimorpha sur Pocillopora verrucosa; et Hapalocarcinus marsupialis sur $P$. verrucosa. Si l'on ajoute les données nouvelles recueillies à Orchid Island lors de cette étude, la faune des crabes brachyoures de Taiwan atteint maintenant 611 espèces.

\section{INTRODUCTION}

Gall crabs, family Cryptochiridae, are the obligate symbionts of stony corals (Scleractinia) inhabiting the coral skeleton by forming a gall or pit inside the substratum of living corallum (Scotto \& Gore, 1981). They not only live within the coral skeleton, but also use the mucus of the host coral as a source of nutrients (Kropp, 1986; Simon-Blecher et al., 1999), and in addition they filter suspended particles (Abelson et al., 1991). They have been known for more than one-and-a-half century, but little is known about their biology, ecology, taxonomy, and zoogeographical distribution, which have thus continuously been puzzling biologists (Kropp, 1990). Recently, there has been a renewed interest in the distribution and behaviour of gall crabs (Simon-Blecher \& Achituv, 1997; Carricart-Ganivet et al., 2004) and some studies have been made on the genera Hapalocarcinus (by Kotb et al., 2002) and Cryptochirus (by Simon-Blecher et al., 1999). The distribution of the Cryptochiridae mainly covers the Pacific and Indian Ocean and includes 18 genera represented by 41 species (Kropp, 1990, 1994, 1995; Manning, 1991; Kropp \& Manning, 1995). Eleven species, belonging to 4 genera, have been recorded from the Atlantic Ocean (Kropp \& Manning, 1987).

Kropp (1990) revealed many morphological inconsistencies and taxonomic errors by previous authors while describing the family. Concentrating on study of the type species and rejecting a previous concept involving host affinity as a generic character, he defined 15 genera of Cryptochiridae occurring in the Pacific Ocean and prepared a key for the females of all known genera of Cryptochiridae.

Orchid Island, a small, remote island $\left(22^{\circ} 1^{\prime} \mathrm{N} 121^{\circ} 5^{\prime} \mathrm{E}\right)$, S.E. of Taiwan, is located in the northwestern Pacific. It has a number of well developed coral reef communities. The island is located at a distance of 30 miles eastward from the Hung-Chung Peninsula. Over 250 species of hard corals have been estimated to occur there. These corals provide various habitats favourable for gall crabs. Until now, only two species of Cryptochiridae, Hapalocarcinus marsupialis Stimpson, 1859 and Pseudocryptochirus viridis Hiro, 1938 have been reported from Taiwan, and those are from the Hung-Chung Peninsula (Yu, 1996; Jeng, 1997, 1998; Ng et al., 2001). In the present study, we examined all specimens collected from Orchid Island according to the key developed by Kropp (1990). The Scanning Electron Microscope (SEM) was used to ascertain marked 
differences in carapace morphology and to elucidate if these differences correspond to a well-defined pattern. From 8 species of host corals, we recorded 9 species of crabs (including the 2 species that had been recorded earlier), representing 9 genera. These are: Cryptochirus coralliodytes Heller, 1861 inhabiting Goniastrea australensis (H. Milne Edwards \& Haime, 1857); Lithoscaptus paradoxus A. Milne-Edwards, 1862 on G. australensis; Hiroia krempfi (Fize \& Serène, 1955) on Hydnophora exesa (Pallas, 1766); Neotroglocarcinus hongkongensis (Shen, 1936) on Turbinaria mesenterina (Lamarck, 1816) and T. peltata (Esper, 1794); Pseudocryptochirus viridis on T. mesenterina; Dacryomaia edmonsoni (Fize \& Serène, 1955) on Psammocora contigua (Esper, 1797); Opecarcinus crescentus (Edmondson, 1925) on Coscinaraea columna (Dana, 1846) and Pavona venosa (Ehrenberg, 1834); Utinomiella dimorpha (Henderson, 1906) on Pocillopora verrucosa (Ellis \& Solander, 1786); and H. marsupialis on P. verrucosa. Various species recorded from the Pacific and Indian Ocean, e.g., those belonging to the 5 genera, Pelycomaia Kropp, 1990, Sphenomaia Kropp, 1990, Cecidocarcinus Kropp \& Manning, 1987, Zibrovia Kropp \& Manning, 1995, and Luciades Kropp \& Manning, 1995, have not been reported from Japan or Taiwan so far.

\section{MATERIAL AND METHODS}

Data collection. - Fragments of coral colonies inhabited by gall crabs were inspected by in situ SCUBA diving and collected at a depth of 1 to $11 \mathrm{~m}$ from the coastal coral reefs of Orchid Island. The sampling sites are shown in fig. 1. Crabs were removed from the corals and identified following the descriptions in Kropp $(1989,1990)$. Female specimens were studied for a concise description of morphology and pit shape. All specimens have been deposited in the National Museum of Marine Biology and Aquarium (NMMBA), Pingtung, Taiwan.

Abbreviations used in the text are as follows: m, meters; mm, millimeters; cl, carapace length; cw, carapace width.

Fixation and preparation for SEM. - Fresh crabs were stored in 95\% ethanol. Various body parts (including carapace, eyestalk, and antennule) were dissected under a dissection microscope and appendages were cleaned by soft brushing. The thoroughly cleaned parts were dried for 4 hours at room temperature. Specimens were sputter-coated with gold and observed in a HITACHI S-3500N SEM operating at $15 \mathrm{kV}$. 


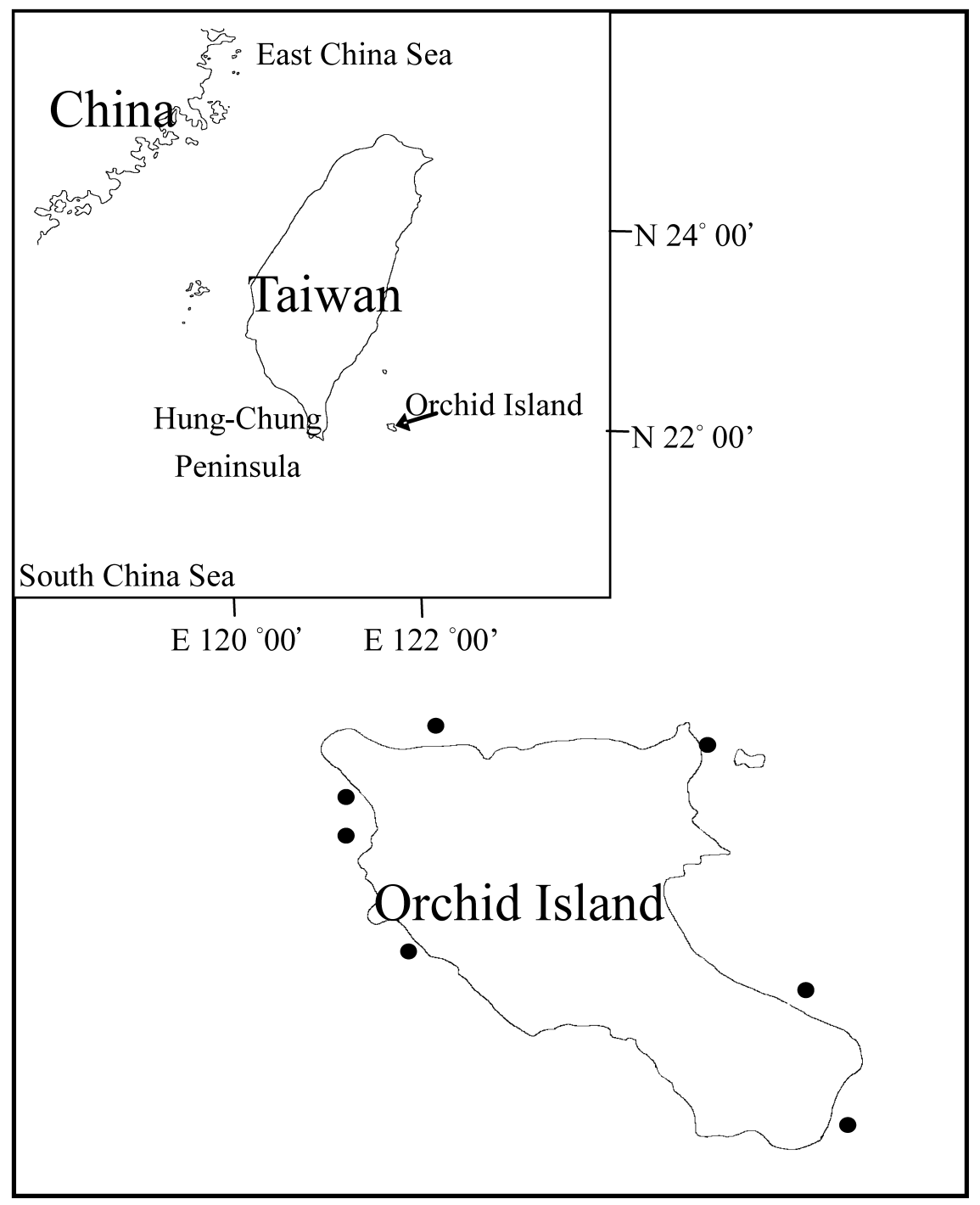

Fig. 1. Map of Taiwan showing sampling sites around Orchid Island.

DESCRIPTIONS

Family CRYPTOCHIRIDAE Paulson, 1875

Cryptochirus coralliodytes Heller, 1861

(fig. 2A)

Cryptochirus coralliodytes Heller, 1861: 19.

Cryptochirus rugosus - Edmondson, 1933: 6.

Troglocarcinus (Favicola) rugosus - Fize \& Serène, 1957: 85.

Favicola rugosus - Serène, 1966: 396. 

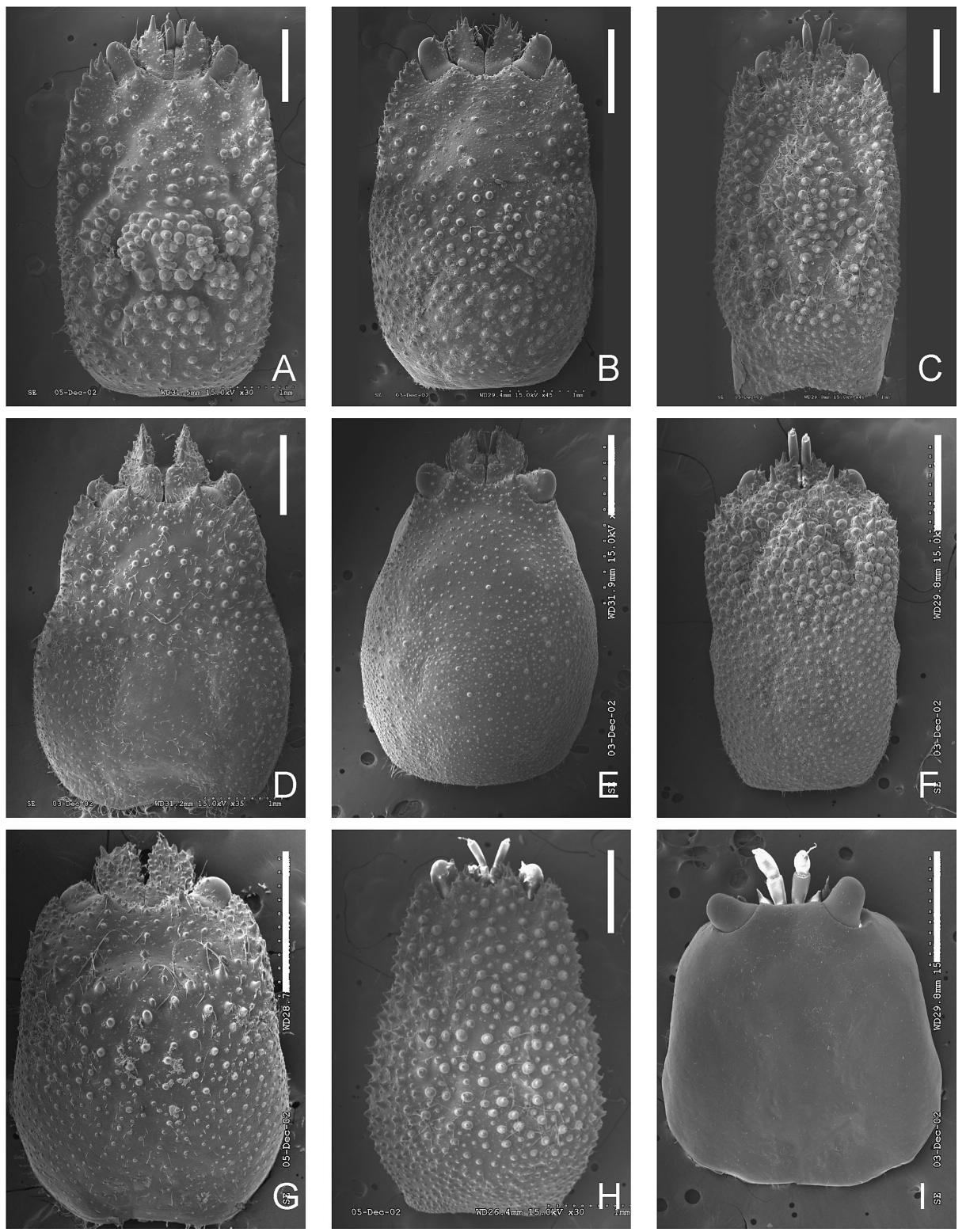

Fig. 2. SEM photographs of the carapaces of all nine species reported, in dorsal view. All females. A, Cryptochirus coralliodytes Heller, 1861; B, Lithoscaptus paradoxus A. Milne-Edwards, 1862; C, Hiroia krempfi (Fize \& Serène, 1955); D, Neotroglocarcinus hongkongensis (Shen, 1936); E, Pseudocryptochirus viridis Hiro, 1938; F, Dacryomaia edmonsoni (Fize \& Serène, 1955); G, Opecarcinus crescentus (Edmondson, 1925); H, Utinomiella dimorpha (Henderson, 1906); I, Hapalocarcinus marsupialis Stimpson, 1859. Scale bar represents $1 \mathrm{~mm}$. 
Favicola rugosum — Lundøer, 1974: 10.

Favicola rugosa - Takeda \& Tamura, 1981a: 43.

Cryptochirus planus — Takeda \& Tamura, 1983.

Favicola plana — Takeda \& Tamura, 1983: 4.

Material examined. - Two females ( NMMBACDC1) $(\mathrm{cl} \times \mathrm{cw}$ : $4.8 \times 4.1 \mathrm{~mm} ; 6.1 \times 4.5 \mathrm{~mm})$, on Goniastrea australensis (H. Milne Edwards \& Haime, 1857), Orchid Island, 27 Nov. 2002, $10 \mathrm{~m}$ depth.

Diagnosis. - Carapace rectangular, longer than broad, deflected anteriorly, mid portion of carapace with clusters of rounded tubercles, mesogastric region inflated, posterior region of carapace isolated by system of grooves. Lateral lobe of antennule elliptical, extends beyond eyestalk, apex marked with prominent spine, shape in dorsal view pointed.

Pit shape. - The opening of the pit is always circular and it forms a cylindrical cavity in the host coral; its diameter is similar to the maximum body width of the crab. The pit depth is approx. 1.7 times the crab's body length.

\section{Lithoscaptus paradoxus A. Milne-Edwards, 1862}

(fig. 2B)

Lithoscaptus paradoxus A. Milne-Edwards, 1862: F10.

Cryptochirus coralliodytes var. rubrolineata - Fize \& Serène, 1957: 40.

Cryptochirus coralliodytes var. fusca — Fize \& Serène, 1957: 40.

Cryptochirus coralliodytes var. parvulus — Fize \& Serène, 1957: 40.

Cryptochirus bani — Fize \& Serène, 1957: 44.

Material examined. - One female (NMMBACDC5) $(\mathrm{cl} \times \mathrm{cw}: 4.31 \times 3.62 \mathrm{~mm})$, on Goniastrea australensis (H. Milne Edwards \& Haime, 1857), Orchid Island, 28 Nov. 2002, 5 m depth.

Diagnosis. - Carapace rectangular, longer than broad, deflected anteriorly, with broad W-shaped depression, cardio-intestinal region outlined by an inverted U-shaped depression. Lateral lobe of antennule oval, extending beyond eyestalk.

Pit shape. - The opening of the pit is always circular and forms a cylindrical cavity in the host coral; its diameter is similar to the crab's body width. The pit depth is approx. 1.5 times the crab's body length.

\section{Hiroia krempfi (Fize \& Serène, 1955)}

(fig. 2C)

Troglocarcinus krempfi Fize \& Serène, 1955a: 378.

Troglocarcinus (Troglocarcinus) krempfi — Fize \& Serène 1957: 79.

Pseudocryptochirus krempfi - Serène, 1966: 396.

Hiroia krempfi — Takeda \& Tamura, 1981b: 20.

Material examined. - One female (NMMBACDC4) $(\mathrm{cl} \times \mathrm{cw}: 3.3 \times 2.6 \mathrm{~mm})$, on Hydnophora exesa (Pallas, 1766), Orchid Island, 27 Nov. 2002, 11 m depth. 
Diagnosis. - Carapace rectangular, longer than broad, not deflected anteriorly, with broad, shallow W-shaped depression, mesogastric region slightly inflated, cardio-intestinal region outlined by depression. Lateral lobe of antennule oval, extending beyond eyestalk, surface with scattered setae.

Pit shape. - The opening of the pit is elliptical-shaped, chamber openings are constricted and lead to oval chambers. Its diameter is similar to the crab's body width. The pit is occupied by crab along its whole body length, and the depth is about equal to that body length.

\section{Neotroglocarcinus hongkongensis (Shen, 1936)}

$$
\text { (fig. 2D) }
$$

Cryptochirus hongkongensis Shen, 1936: 23.

Pseudocryptochirus hongkongensis — Takeda \& Tamura, 1981b: 15.

Troglocarcinus monodi — Fize \& Serène, 1955a: 375.

Neotroglocarcinus monodi — Fize \& Serène, 1957: 137.

Neotroglocarcinus hongkongensis — Kropp, 1988: 870.

Material examined. - Two females (NMMBACDC6) $(\mathrm{cl} \times \mathrm{cw}: 2.4 \times 2.2 \mathrm{~mm} ; 3.3 \times 2.9 \mathrm{~mm}$ ), on Turbinaria mesenterina (Lamarck, 1816) and T. peltata (Esper, 1794), Orchid Island, 27 Nov. 2002, 3 m depth.

Diagnosis. - Carapace vase-shaped, longer than broad, slightly deflected anteriorly; with irregular depression flanking mesogastric region, latter slightly inflated, cardio-intestinal region outlined by depression. Lateral lobe of antennule trianglular, extending beyond eyestalk. Apex marked with prominent spine, shape in dorsal view pointed.

Pit shape. - The opening of the pit is crescent-shaped, a prominent dome is formed on the surface or back of the host coral. Its diameter is longer than 1.5 times the crab's body width. The depth of the pit is approx. 1.3 times the crab's body length.

\section{Pseudocryptochirus viridis Hiro, 1938}

(fig. 2E)

Pseudocryptochirus viridis Hiro, 1938: 149.

Material examined. - One female (NMMBACDC8) $(\mathrm{cl} \times \mathrm{cw}: 2.3 \times 1.9 \mathrm{~mm})$, on Turbinaria mesenterina (Lamarck, 1816), Orchid Island, 27 Nov. 2002, 8 m depth.

Diagnosis. - Carapace vase-shaped, longer than broad, not deflected anteriorly, mesogastric region very slightly inflated, cardio-intestinal region not outlined by depression. Lateral lobe of antennule quadrangular, extending beyond eyestalk.

Pit shape. - The opening of the pit is crescent-shaped and forms a shallow depression, the depression is shaped along the crab's carapace and ambulatory 
legs. Its diameter is similar to the crab's body width. The depth of the depression is approx. 1.3 times the crab's body thickness.

\section{Dacryomaia edmonsoni (Fize \& Serène, 1955)}

(fig. 2F)

Cryptochirus edmonsoni Fize \& Serène, 1955b: 379.

Dacryomaia edmonsoni - Kropp, 1990: 422.

Material examined. - Two females (NMMBACDC2) $(\mathrm{cl} \times \mathrm{cw}: 4.5 \times 3.0 \mathrm{~mm} ; 4.7 \times 3.1 \mathrm{~mm})$, on Psammocora contigua (Esper, 1797), Orchid Island, 28 Nov. 2002, $5 \mathrm{~m}$ depth.

Diagnosis. - Carapace rectangular, longer than broad, deflected anteriorly; internal orbital angle extending beyond the external orbital angle and the anterior part of the carapace is marked with a deep, inverted V-shaped groove flanking the mesogastic region, the latter being inflated. Lateral lobe of antennule oval, extending to or just beyond eyestalk.

Pit shape. - The opening of the pit is semicircular, a canopy-shaped tunnel is formed on the surface of the host coral. Its diameter is longer than the crab's body width. The length of the pit is approx. 1.2 times the crab's body length.

\section{Opecarcinus crescentus (Edmondson, 1925)}

(fig. 2G)

Cryptochirus crescentus Edmondson, 1925: 33.

Pseudocryptochirus crescentus — Utinomi, 1944: 697.

Troglocarcinus crescentus — Fize \& Serène, 1957: 62.

Opecarcinus crescentus — Kropp \& Manning, 1987: 9; Kropp, 1989: 99.

Material examined. - One female and 1 male (NMMBACDC7) $(\mathrm{cl} \times \mathrm{cw}: 2.5 \times 2.0 \mathrm{~mm} ; 1.9$ $\times 1.6 \mathrm{~mm}$ ), on Coscinaraea columna (Dana, 1846) and Pavona venosa (Ehrenberg, 1834), Orchid Island, 27 Nov. 2002, $10 \mathrm{~m}$ depth.

Diagnosis. - Carapace vase-shaped, longer than broad, deflected anteriorly, carapace ornamented with numerous tubercles and the cornea situated terminally on the eyestalk, with transverse depression on protogastric region, mesogastric region slightly inflated, cardio-intestinal region outlined by depression. Lateral lobe of antennule triangular, extending beyond the eyestalk, bearing scattered granules and setae dorsally.

Pit shape. - The opening of the pit is crescent-shaped, a canopy-shaped tunnel is formed on the surface of the host coral. Its diameter is longer than the crab's body width. The depth of the pit is approx. 1.6 times the crab's body length. 


\section{Utinomiella dimorpha (Henderson, 1906)}

(fig. 2H)

Cryptochirus dimorphus Henderson, 1906: 214.

Pseudocryptochirus kahe - McCain \& Coles, 1979: 81.

Pseudocryptochirus dimorphus — Takeda \& Tamura, 1980: 47.

Utinomia dimorpha - Takeda \& Tamura, 1981b: 23.

Utinomiella dimorpha — Kropp \& Takeda, 1988: 29.

Material examined. - One female (NMMBACDC9) $(\mathrm{cl} \times \mathrm{cw}: 3.2 \times 2.1 \mathrm{~mm})$, on Pocillopora verrucosa (Ellis \& Solander, 1786), Orchid Island, 27 Nov. 2002, $3 \mathrm{~m}$ depth.

Diagnosis. - Carapace vase-shaped, longer than broad, not deflected anteriorly, with broad, shallow depression, mesogastric region slightly inflated, cardiointestinal region outlined by depression. Lateral lobe of antennule rectangular, extending to tip of eyestalk, dorsally covered with setae.

Pit shape. - The opening of the pit is usually circular-shaped but may occasionally be oval-shaped, chamber openings are constricted and lead to cylindrical chambers. The entire chamber surface is lined with a smooth calcareous integument. Its diameter is longer than the crab's body width. The depth of the pit is approx. 1.4 times the crab's body length.

\section{Hapalocarcinus marsupialis Stimpson, 1859}

(fig. 2I)

Hapalocarcinus marsupialis Stimpson, 1859: 412; Serène et al., 1974: 20; Monod, 1976: 26; Serène et al., 1976: 20; Takeda \& Tamura, 1986: 61.

Cryptochirus marsupialis — Taylor, 1971: 100.

Material examined. - One female (NMMBACDC3) $(\mathrm{cl} \times \mathrm{cw}: 3.9 \times 3.7 \mathrm{~mm})$, on Pocillopora verrucosa (Ellis \& Solander, 1786), Orchid Island, 27 Nov. 2002, $8 \mathrm{~m}$ depth.

Diagnosis. - Carapace quadrate, as long as broad, not deflected anteriorly, slightly convex in lateral view, lacking depressions. Antennule not produced past midlength of eyestalk, surface smooth, apex pointed or rounded.

Pit shape. - The branches are flattened spheres formed by two valves in branching corals, and coalescing together, forming a open or closed gall. The width of the gall is greater than 2.8 times the crab's body width. The length of the gall is approx. 2.3 times the crab's body length.

\section{DISCUSSION}

In the Indo-Pacific, a variety of small crabs with different lifestyles is found on living coral (Garth, 1964; Patton, 1966, 1974). Although some species are facultative symbionts or merely wanderers onto the living coral, many are obligatory symbionts showing a variety of morphological adaptations and usually being specific 
to a given coral family (Patton, 1976). All members of the family Cryptochiridae are obligate symbionts of scleractinian corals.

Orchid Island is a small island off the southeastern coast of Taiwan. It was built up from the bottom of the sea by the accumulation of lava from volcanic eruptions. Healthy fringing reefs surrounding the island are inhabited by different scleractinian corals. The island is situated in the pathway of the northward flowing warm-water Kuroshio Current (begins where the North Equatorial Current approaches the Philippines and continues northward east of Taiwan, and then crosses a ridge between Kyushu and the Okinawa Islands, responding by forming the East China Sea meander), which may be driving various larvae of coral and many other invertebrate fauna into the coral reefs from the northern Philippines.

A total of 41 species representing 18 genera has been reported in the Pacific and Indian Ocean (Kropp, 1990, 1994, 1995; Manning, 1991; Kropp \& Manning, 1995). Among which 13 genera have been reported from Japan and Vietnam, respectively. The gall crab fauna from Japan shows similarity with that of Vietnam, but interestingly the genus Utinomiella is present in Japan but not reported from the Vietnamese gall crab fauna. In contrast, the genus Plycomaia is present in the Vietnamese crab community, but not reported from Japan. In this study, we recorded 9 species of gall crabs representing 9 genera (including the genus Utinomiella), which are common to the gall crab species assemblage of Japan. The occurrence of the genus Utinomiella on our study sites, indicates similarity of the gall crab community on Orchid Island with that of Japan (table I).

In terms of either the coral or the gall crab community, the Pacific Ocean (41 species) supports a higher diversity than found in the Atlantic Ocean (11 species). Furthermore, corresponding to the coral distribution in the Pacific Ocean, the diversity of gall crab communities shows a decreasing trend from the western Pacific to the eastern Pacific. The insufficient number of islands in the eastern Pacific to support corals and subsequently gall crabs, might be one of the explanations for this phenomenon (Rosen, 1984).

Our study provides a biogeographical link between high diversity centres (IndoPacific) and the peripheral regions (e.g., Kyushu and the Okinawa Islands, Japan) both for the corals and for the associated coral fauna.

\section{ACKNOWLEDGEMENTS}

We thank Dr. Chang-Feng Dai for definitive identification of the host corals. We are grateful to Dr. Ping-Ho Ho, Dr. Ming-Hui Cheng, Mr. Shao-Hung Peng, and Mr. Chia-Hsin Lin for their help in various stages of the work. This study was supported by a research grant from the National Science Council, Taiwan, R.O.C. (NSC-92-3114-B-020-004). 


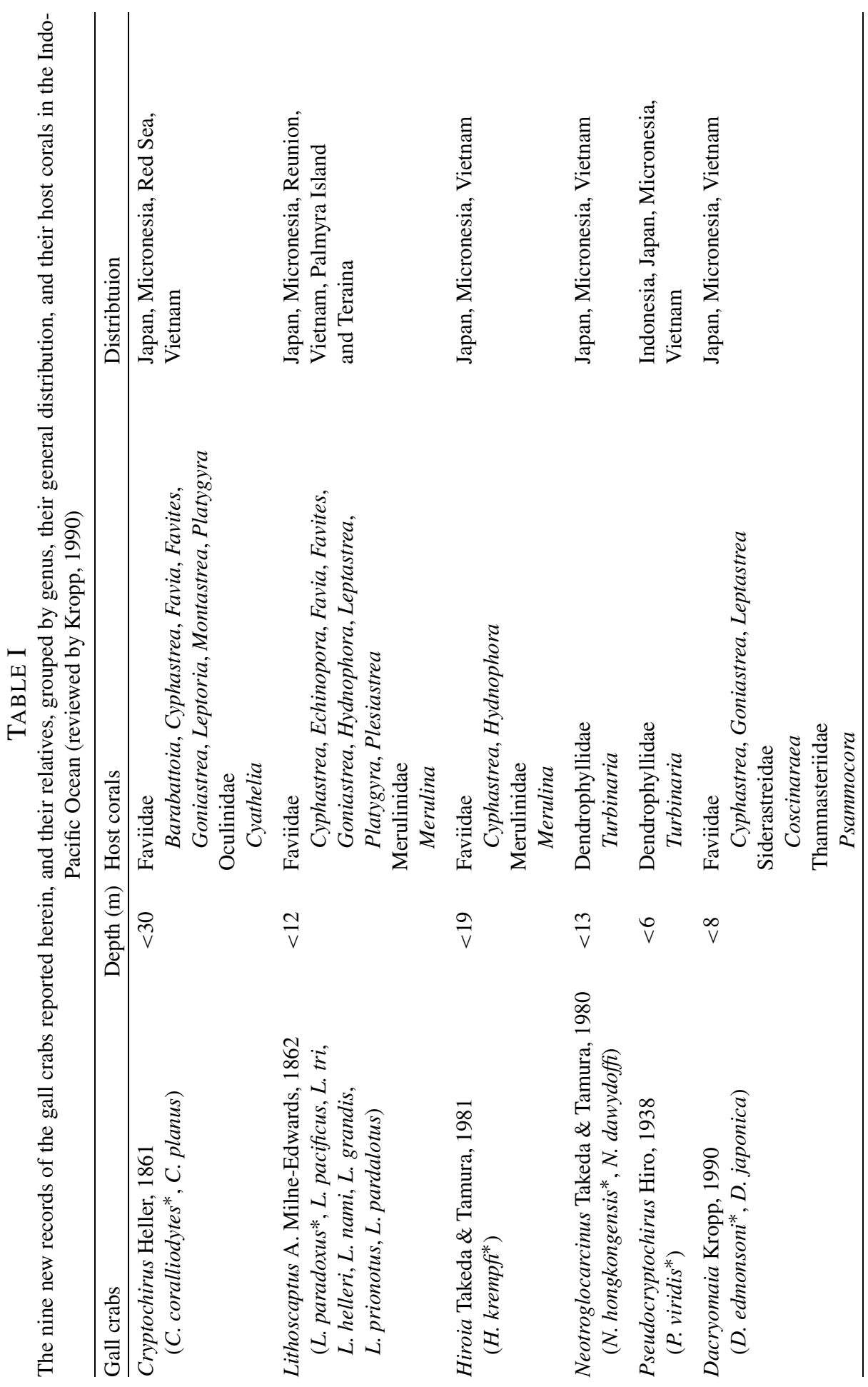




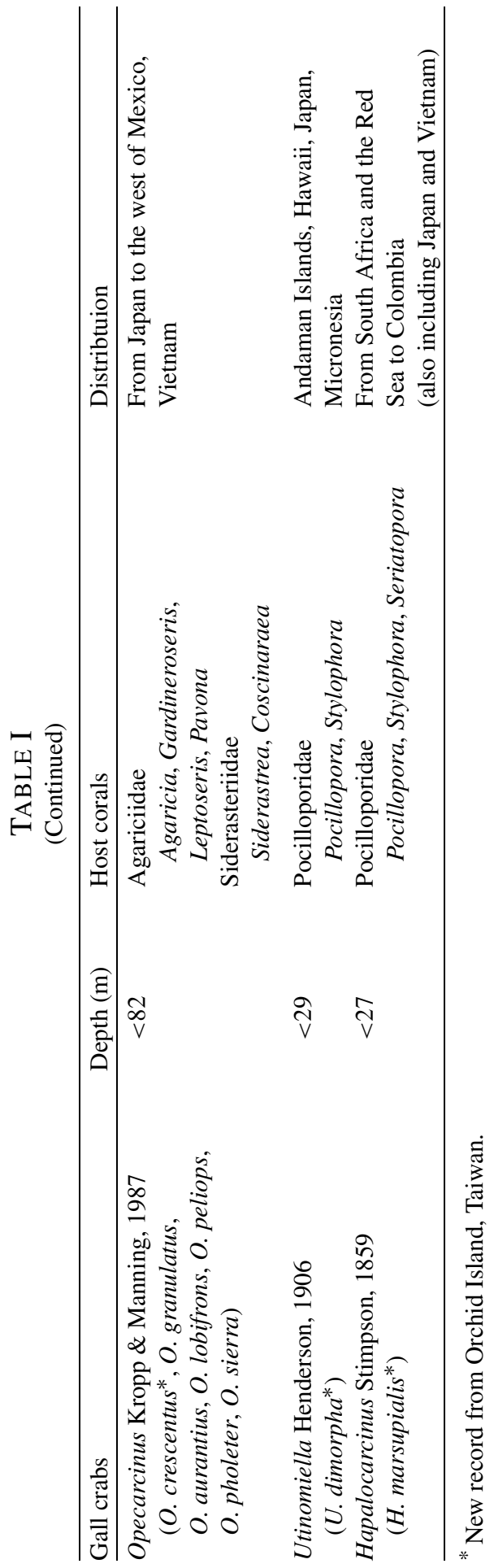




\section{REFERENCES}

Abelson, A., B. S. Galil \& Y. LoYA, 1991. Skeletal modifications in stony corals caused by indwelling crabs: hydrodynamical advantages for crab feeding. Symbiosis, 10: 233-248.

Carricart-Ganivet, J. P., L. F. Carrera-Parra, L. I. Quan-Young \& M. S. GarcíaMADRIGAL, 2004. Ecological note on Troglocarcinus corallicola (Brachyura: Cryptochiridae) living in symbiosis with Manicina areolata (Cnidaria: Scleractinia) in the Mexican Caribbean. Coral Reefs, 23: 215-217.

Edmondson, C. H., 1925. Marine zoology of the central Pacific: Crustacea. Bull. Bernice P. Bishop Mus., 27: 3-62.

— - 1933. Cryptochirus of the central Pacific. Occas. Pap. Bernice P. Bishop Mus., 10 (5): 1-23.

FIZE, A. \& R. SERÈnE, 1955a. Note préliminaire sur huit espèces nouvelles, dont une d'un genre nouveau, d'Hapalocarcinidés. Bull. Soc. zool. France, 80: 375-378.

— — \& — , 1955b. Note préliminaire sur quatre espèces nouvelles d'Hapalocarcinidés avec quelques remarques au sujet du Cryptochirus rugosus Edmonson [sic]. Bull. Soc. zool. France, 80: $379-382$.

——\&_—, 1957. Les Hapalocarcinidés du Vietnam. Arch. Mus. natn. Hist. nat., Paris, 7: 1-202.

Garth, J. S., 1964. The Crustacea Decapoda (Brachyuran and Anomura) of Eniwetok Atoll, Marshall Islands, with special reference to the obligate commensals of branching corals. Micronesica, 1: 137-144.

Heller, C., 1861. Synopsis der im rothen Meere vorkommenden Crustaceen. Verhandlungen der Kaiserlich-Königlichen Zoologisch-Botanischen Gesellschaft, Wien, 11: 1-32.

HENDERSON, J. R., 1906. On a new species of coral-infesting crab taken by the R.I.M.S. "Investigator" at the Andaman Islands. Ann. Mag. nat. Hist., 7 (18): 211-219.

Hiro, F., 1938. A new coral-inhabiting crab, Pseudocryptochirus viridis gen. et sp. nov. (Hapalocarcinidae, Brachyura). Zool. Mag., Tokyo, 50: 149-151.

JENG, M. S., 1997. Studies on the land and aquatic decapod crustacean fauna of the Kenting National Park (II) - Communities of decapod crustaceans around the sea: i-ii, 1-66. (Kenting National Park, Ministry of the Interior, Pingtung). [In Chinese.]

— _ 1998. The prawns and crabs of the Kenting National Park. Kenting National Park Hand Guides, 14: 133. (Kenting National Park, Ministry of the Interior, Pingtung). [In Chinese.]

Kotb, M. M. A. \& R. G. Hartnoll, 2002. Aspects of the growth and reproduction of the coral gall crab Hapalocarcinus marsupialis. Journ. Crust. Biol., 22 (3): 558-566.

KROPP, R. K., 1986. Feeding biology and mouthpart morphology of three species of coral gall crabs (Decapoda: Cryptochiridae). Journ. Crust. Biol., 6 (3): 377-384.

- -1988 . The status of Cryptochirus hongkongensis Shen, 1936 (Brachyura: Cryptochiridae). Proc. biol. Soc. Washington, 101 (4): 866-871.

- - 1989. A revision of the Pacific species of gall crabs, genus Opecarcinus (Crustacea: Cryptochiridae). Bull. mar. Sci., 45: 98-129.

- -1990 . Revision of the genera of gall crabs (Crustacea: Cryptochiridae) occurring in the Pacific Ocean. Pacific Sci., 44: 417-448.

— - 1994. The gall crabs (Crustacea: Decapoda: Brachyura: Cryptochiridae) of the Rumphius expeditions revisited, with descriptions of three new species. Raffles Bull. Zool., 42: 521-538.

- - 1995. Lithoscaptus pardalotus, a new species of coral-dwelling gall crab (Crustacea: Brachyura: Cryptochiridae) from Belau. Proc. biol. Soc. Washington, 108 (4): 637-642.

KROPP, R. K. \& M. TAKEDA, 1988. Utinomiella, a replacement name for Utinomia Takeda and Tamura, 1981 (Crustacea, Decapoda), non Tomlinson, 1963 (Crustacea, Acrothoracica). Bull. biogeogr. Soc., Japan, 43: 29.

Kropp, R. K. \& R. B. Manning, 1987. The Atlantic gall crabs, family Cryptochiridae (Crustacea: Decapoda: Brachyura). Smithson. Contrib. Zool., 462: 1-21. 
— — \& — - 1995. Crustacea Decapoda: two new genera and species of deep water gall crabs from the Indo-West Pacific (Cryptochiridae). In: A. CrosniER (ed.), Résultats des Campagnes MUSORSTOM, 15. Mém. Mus. natn. Hist. nat., Paris, 168: 531-539.

LUNDøER, S., 1974. A checklist of the marine Brachyura in the reference collection at PMBC, Thailand. Phuket mar. biol. Centre Res. Bull., 4: 3-11.

Manning, R. B., 1991. Crustacea Decapoda: Cecidocarcinus zibrowii, a new deep-water gall crab (Cryptochiridae) from New Caledonia. In: A. CrosniER (ed.), Résultats des Campagnes MUSORSTOM, 9. Mém. Mus. natn. Hist. nat., Paris, 152: 515-520.

McCain, J. C. \& S. L. Coles, 1979. A new species of crab (Brachyura, Hapalocarcinidae) inhabiting pocilloporid corals in Hawaii. Crustaceana, 36: 81-89.

Milne-EdwardS, A., 1862. Faune carcinologique de l'île de la Réunion, Annexe F de l'ouvrage intitulé: Notes sur l'île de la Réunion par L. Maillard. In: L. MAILLARD, Notes sur l'île de la Réunion (Bourbon): F1-F16, pls. 17-19. (Paris).

MONOD, T., 1976. Parasitic, commensal, and inquiline crustaceans collected during the Rumphius Expedition II. Osean. Indonesia, 6: 23-27.

NG, P. K. L., C. H. WANG, P. H. Ho \& H. T. SHIH, 2001. An annotated checklist of brachyuran crabs from Taiwan (Crustacea: Decapoda). Natn. Taiwan Mus. spec. Publ. Ser., 11: 48.

Patton, W. K., 1966. Decapod Crustacea commensal with Queensland branching corals. Crustaceana, 10: 271-295.

_ - 1974. Community structure among the animals inhabiting the coral Pocillopora damicornis at Heron Island, Australia. In: W. B. Vernberg (ed.), Symbiosis in the sea: 219-243. (University of South Carolina Press).

— - 1976. Animal associates of living reef corals. In: O. A. Jones \& B. ENDEAn (eds.), Biology and geology of coral reefs, 3, Biology, 2: 1-36. (Academic Press, New York).

Rosen, B. R., 1984. Reef coral biogeography and climate through the Late Cainozoic: just islands in the sun or a critical pattern of islands? In: P. BRENCHLEY (ed.), Fossil and climate: 201-262. (Wiley, New York).

SCOTto, L. E. \& R. H. GoRE, 1981. Studies on decapod Crustacea from the Indian River region of Florida. 23. The laboratory cultured zoeal stages of the coral gall-forming crab Troglocarcinus corallicola Verrill, 1908 (Brachyura: Hapalocarcinidae) and its familial position. Journ. Crust. Biol., 1 (4): 486-505.

SERĖNE, R., 1966. Note sur la taxonomie et la distribution géographique des Hapalocarcinidae (Decapoda: Brachyura). Proc. Symp. Crustacea, Ernakulam, 12-15 January 1965, 1: 395-398. (Mar. biol. Assoc. India).

Serène, R., K. Romimohtarto \& M. K. Moosa, 1974. The Hippidea and Brachyura collected by the Rumphius Expedition I. Osean. Indonesia, 1: 17-26.

— - , — \& — - 1976. Hippidea, Brachyura and Stomatopoda of the Rumphius Expedition II. Osean. Indonesia, 6: 15-21.

SHEN, C. J., 1936. Notes on the family Hapalocarcinidae (coral-infesting crabs) with descriptions of two new species. Hong Kong nat., 5 (suppl.): 21-26.

Simon-Blecher, N. \& Y. AChituv, 1997. Relationship between the coral pit crab Cryptochirus coralliodytes Heller and its host coral. Journ. exp. mar. Biol. Ecol., 215: 93-102.

Simon-Blecher, N., A. Chemedanov, N. Eden \& Y. Achituv, 1999. Pit structure and trophic relationship of the coral pit crab Cryptochirus coralliodytes. Mar. Biol., Berlin, 134: 711-717.

Stimpson, W., 1859. Communication (Hapalocarcinus marsupialis). Proc. Boston Soc. nat. Hist., 6: $412-413$.

TAKedA, M. \& Y. TAMURA, 1980. Coral-inhabiting crabs of the family Hapalocarcinidae from Japan. V. Genus Cryptochirus. Res. Crustacea, 10: 45-56.

— — \& — , 1981a. Coral-inhabiting crabs of the family Hapalocarcinidae from Japan. VII. Genus Favicola. Res. Crustacea, 11: 41-50. 
— — \& — , 1981b. Coral-inhabiting crabs of the family Hapalocarcinidae from Japan. VIII. Genus Pseudocryptochirus and two new genera. Bull. biogeogr. Soc., Japan, 36 (3): 14-27.

— $\&-\ldots, 1983$. Coral inhabiting crabs of the family Hapalocarcinidae from Japan. IX. A small collection made at Kushimoto and Koza, the Kii Peninsula. Bull. natn. Sci. Mus., Tokyo, (A, Zool.) 9 (1): 1-11.

- $-\&-\ldots, 1986$. Coral-inhabiting crabs of the family Hapalocarcinidae from Japan. XI. Biogeographical distribution. Bull. biogeogr. Soc., Japan, 41 (8): 61-70.

TAYLOR, J. D., 1971. Crustacea: Brachyura and Anomura from Diego Garcia. Atoll Res. Bull., 149: 93-101.

Utinomi, H., 1944. Studies on the animals inhabiting reef corals, III. A revision of the family Hapalocarcinidae (Brachyura), with some remarks on their morphological peculiarities. Palao trop. biol. Stn. Stud., 2 (4): 687-731.

Yu, H. P., M. S. JenG, T. Y. ChAN, P. H. Ho \& J. Y. Shy, 1996. Studies on the land and aquatic decapod crustacean fauna of the Kenting National Park: i-ii, 1-79. (Kenting National Park, Ministry of the Interior, Pingtung). [In Chinese.] 